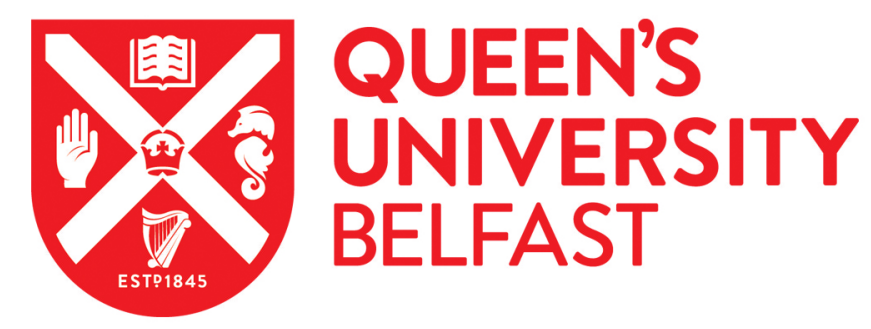

\title{
A study on the improvement iron nutrition of peanut intercropping with maize on nitrogen fixation at early stages of growth of peanut on a calcareous soil
}

Zuo, Y. M., Liu, Y. X., Zhang, F. S., \& Christie, P. (2004). A study on the improvement iron nutrition of peanut intercropping with maize on nitrogen fixation at early stages of growth of peanut on a calcareous soil. Soil Science and Plant Nutrition, 50(7), 1071-1078.

Published in:

Soil Science and Plant Nutrition

Queen's University Belfast - Research Portal:

Link to publication record in Queen's University Belfast Research Portal

\section{General rights}

Copyright for the publications made accessible via the Queen's University Belfast Research Portal is retained by the author(s) and / or other copyright owners and it is a condition of accessing these publications that users recognise and abide by the legal requirements associated with these rights.

Take down policy

The Research Portal is Queen's institutional repository that provides access to Queen's research output. Every effort has been made to ensure that content in the Research Portal does not infringe any person's rights, or applicable UK laws. If you discover content in the Research Portal that you believe breaches copyright or violates any law, please contact openaccess@qub.ac.uk. 


\title{
A Study on the Improvement Iron Nutrition of Peanut Intercropping with Maize on Nitrogen Fixation at Early Stages of Growth of Peanut on a Calcareous Soil
}

\author{
Yuanmei Zuo, Yongxiu Liu, Fusuo Zhang ${ }^{1}$, and Peter Christie* \\ Department of Plant Nutrition, China Agricultural University; Key Laboratory of Plant Nutrition, Ministry of Agricul- \\ ture; Key Laboratory of Plant-Soil Interactions, Ministry of Education, 2 Yuanmingyuan West Road, \\ Beijing 100094, P.R. China; and *Agricultural and Environmental Science Department, \\ Queen's University Belfast, Newforge Lane, Belfast BT9 5PX, UK
}

Received May 8, 2004; accepted in revised form June 20, 2004

\begin{abstract}
A glasshouse study employing a split-root technique was conducted to investigate the influence of intercropping with maize (Zea mays $\mathrm{L}$.) in a calcareous soil on $\mathrm{N}_{2}$ fixation by peanut (Arachis hypogaea L.) at early stages of growth. In this intercropping system, competitive interactions between maize and peanut for $\mathrm{N}$ and improvement of $\mathrm{Fe}$ uptake were likely to be important factors affecting $\mathrm{N}_{2}$ fixation of peanut. The experiment was comprised of three treatments which included treatment I: peanut monocropping; treatment II: maize/peanut intercropping (the major and the minor compartments with low N, $50 \mathrm{mg} \mathrm{kg}^{-1}$ ); treatment III: maize/peanut intercropping (the major compartment with low N, $50 \mathrm{mg} \mathrm{kg}^{-1}$ and the minor compartment with high, $\mathrm{N} 200 \mathrm{mg} \mathrm{kg}^{-1}$ ). The minor compartment of treatment III was fertilized with $200 \mathrm{mg} \mathrm{kg}^{-1} \mathrm{~N}$ for reducing or eliminating the competition of $\mathrm{N}$ coming from intercropping maize. Intercropping with maize corrected $\mathrm{Fe}$ chlorosis of peanut by significantly increasing plant Fe concentration and uptake. Compared with the monocropping treatment, iron uptake increased from intercropping treatment II and III by 22 and $24 \%$ per plant, 30 and $29 \%$ shoots, 38 and $60 \%$ nodules. Iron uptake by the root nodules was especially enhanced in the intercropping system. In contrast, intercropping with maize had little effect on $\mathrm{NO}_{3}{ }^{-}-\mathrm{N}$ concentrations in the soil rhizosphere of peanut or on $\mathrm{N}$ concentrations and uptake by peanut compared with plants in monoculture. The results indicate that the improvement in $\mathrm{Fe}$ nutrition was an important factor promoting $\mathrm{N}_{2}$ fixation by peanut in the intercropping system at the flowering stage of peanut growth, and that competition for $\mathrm{N}$ by intercropped maize had little effect on $\mathrm{N}_{2}$ fixation by peanut under the experimental conditions.
\end{abstract}

Key Words: intercropping, iron deficiency chlorosis, nutrient competition, split-root.

Iron is an essential nutrient required by both legume and root nodule bacteria for many metabolic functions at several key stages in the symbiotic $\mathrm{N}_{2}$ fixation process and is critical for $\mathrm{N}_{2}$ fixation due to its role in the activity of both leghemoglobin and nitrogenase (Dakora 1995; Kaiser et al. 2003). These induce $\mathrm{N}_{2}$-fixing nodules on the roots of legumes and in this symbiotic state have a very high demand for $\mathrm{Fe}$, since several polypeptides made specifically in the nodule (e.g. nitrogenase and leghemoglobin) are Fe-proteins (Johnston et al. 2001; Wexler et al. 2003; Benson et al. 2004). Some

To whom correspondence should be addressed. Fax: $+86-10-$ 62891016. E-mail: zhangfs@cau.edu.cn legume species of soybean (Glycine max L. Merr.) and Lupinus angustifolius showed that induction of $\mathrm{Fe}-$ deficiency responses (proton release and $\mathrm{Fe}(\mathrm{III})$ reduction) is much stronger in the roots of plants that have actively fixing nodules than in the roots of uninoculated plants, and $\mathrm{Fe}$ is directly involved in nodule initiation and nodule development (Terry et al. 1991; Tang et al. 1992; Levier 1996). Peanut inoculated with Brady rhizobium sp. has shown that Fe-deficient plants initiated nodules but had decreased nodule development, lowered amount of leghemoglobin in nodules, fewer bacteroids present in nodules, and lower $\mathrm{N}_{2}$ fixation activity (O'Hara et al. 1988a, b). These studies demonstrate that Fe plays a key role in nitrogen-fixing symbioses. 
Iron deficiency chlorosis in peanut is one of the most common yield limiting nutrients and serious economic problems in peanut monocropping systems on calcareous soils in northern China, but is much less commonly observed in peanut / maize intercropping systems. The maize/peanut intercropping improved $\mathrm{Fe}$ nutrition, increased Fe uptake and corrected Fe deficiency chlorosis symptoms in peanut. Particularly there is considerable interest in devising practical agronomic approaches for the correction or avoidance of Fe deficiency in peanut crops and intercropping has become the most common cropping system for peanut production in northern China (Zuo 1997). Iron, an important component of peanut nitrogenase, participates directly in $\mathrm{N}_{2}$ fixation. The improvement in Fe nutrition of peanut by intercropping with maize may therefore influence $\mathrm{N}_{2}$ fixation by peanut.

A legume-non-legume intercrop provides excellent intercropping advantages which are mainly from the $\mathrm{N}$ efficiency of intercrop systems. The success of intercrop farming systems depends initially on effective $\mathrm{N}_{2}$ fixation and subsequent transfer of $\mathrm{N}$ to the non-legume. The non-legume crop has a unique capacity to lower the mineral $\mathrm{N}$ concentration in the rhizosphere of legume to an extent that symbiotic $\mathrm{N}_{2}$ fixation on an individual plant basis expressed as \% NDFA ( $\mathrm{N}$ derived from atmosphere) can actually be increased over the sole-crop legume. The negative effect of residual $\mathrm{N}$ or fertilizer $\mathrm{N}$ on fixation of atmospheric $\mathrm{N}_{2}$ can be reduced by intercropping through competition from the non-leguminous crop for available soil N (Jensen 1996; Ito et al. 1997; Dakora 1998; Karpenstein-Machan and Stuelpnagel 2000).

In our intercropping systems, the two factors that may affect $\mathrm{N}_{2}$ fixation of peanut are: competition for $\mathrm{N}$ by the intercropped maize and the improvement of $\mathrm{Fe}$ nutrition of peanut. Effects of competition for $\mathrm{N}$ by intercropping maize on peanut $\mathrm{N}_{2}$ fixation must therefore be eliminated (or at least decreased) to study the effects of improvement of $\mathrm{Fe}$ nutrition of intercropped peanut on $\mathrm{N}_{2}$ fixation. The aim of the present study was to investigate whether competition for $\mathrm{N}$ by intercropped maize or the improvement of $\mathrm{Fe}$ nutrition of intercropped peanut had the greater effect on peanut $\mathrm{N}_{2}$ fixation in maize/peanut intercropping systems at the flowering stage of peanut.

\section{MATERIALS AND METHODS}

Rhizobox design. Plants were grown in two kinds of PVC rhizoboxes as shown in Fig. 1. The design used for intercropping (Fig. 1A) was divided by a PVC plate into two compartments. The larger compartment

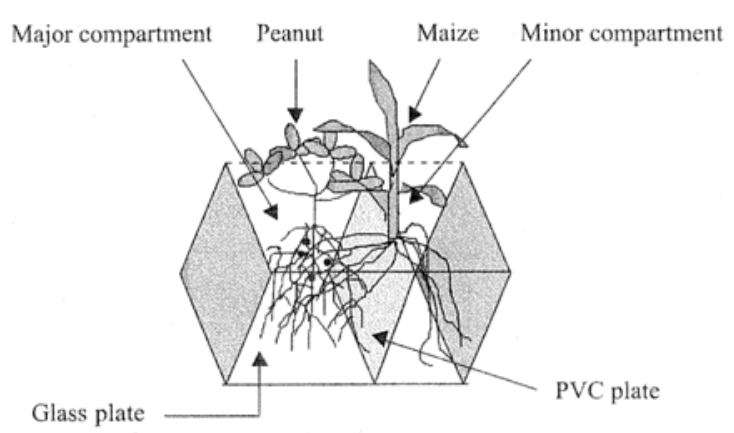

A: intercropping

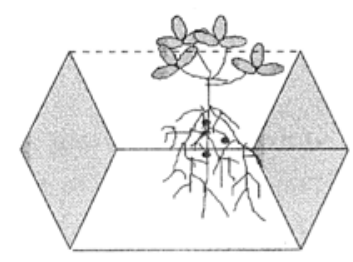

B: monocropping

Fig. 1. Diagrammatic representation of the rhizobox design for intercropping (A) and monocropping (B).

occupied two-thirds of the pot volume and the smaller occupied one-third. All peanut roots and the majority of roots of maize grew in the major compartment in intercropping system (just a few roots of maize were in minor compartment). The other design, used for monocropping, had the same dimensions but was not separated into two compartments (Fig. 1B). One side of each rhizobox consisted of a glass plate to permit observation of plant root growth. The experiment was comprised of three treatments with four replicates per treatment, treatment I: peanut monocropping; treatment II: maize/peanut intercropping (the major and the minor compartments with low $\mathrm{N} 50 \mathrm{mg} \mathrm{kg}^{-1}$ as $\left.\mathrm{Ca}\left(\mathrm{NO}_{3}\right)_{2}\right)$; treatment III: maize/ peanut intercropping (the major compartment with low $\mathrm{N} 50 \mathrm{mg} \mathrm{kg}^{-1}$ and the minor compartment with high $\mathrm{N} 200 \mathrm{mg} \mathrm{kg}^{-1}$ as $\left.\mathrm{Ca}\left(\mathrm{NO}_{3}\right)_{2}\right)$. The minor compartment of treatment III was fertilized $200 \mathrm{mg} \mathrm{kg}^{-1} \mathrm{~N}$ for reducing or eliminating the competition of $\mathrm{N}$ coming from intercropping maize.

Properties and treatment of the calcareous soil. The calcareous sandy soil used in the experiments was collected from the plough layer of a calcareous meadow on a farm near Beijing, North China $\left(39^{\circ} 40^{\prime} \mathrm{N}, 116^{\circ} 15^{\prime} \mathrm{E}\right)$. It had the following properties: $\mathrm{pH}\left(\mathrm{CaCl}_{2}\right) 8.3, \mathrm{CaCO}_{3} 8.32 \%$, organic matter $0.39 \%$, DTPA-Fe $4.52 \mathrm{mg} \mathrm{kg}^{-1}$, total $\mathrm{N} 0.027 \%$, Olsen-P $3.9 \mathrm{mg} \mathrm{kg}^{-1}, \mathrm{NH}_{4} \mathrm{OAc}-\mathrm{K} 60.4 \mathrm{mg} \mathrm{kg}^{-1}$. The soil was air-dried, sieved $(<1 \mathrm{~mm})$, and amended with basal nutrients at the following concentration $\left(\mathrm{mg} \mathrm{kg}^{-1}\right)$ : $\mathrm{N} 50$ 
as $\mathrm{Ca}\left(\mathrm{NO}_{3}\right)_{2} ; \mathrm{P} 150$ and $\mathrm{K} 189$ as $\mathrm{KH}_{2} \mathrm{PO}_{4} ; \mathrm{Mg} 50$ as $\mathrm{MgSO}_{4} ; \mathrm{Zn} 5$ as $\mathrm{ZnSO}_{4}$, and $\mathrm{Cu} 5$ as $\mathrm{CuSO}_{4}$.

Plant growth. Peanut (cv. Haihua) and maize (cv. Danyu) seeds of uniform size were surface sterilized in $5 \%(\mathrm{v} / \mathrm{v}) \mathrm{H}_{2} \mathrm{O}_{2}$ for $30 \mathrm{~min}$, washed with deionized water and germinated at $25^{\circ} \mathrm{C}$ in the dark in sterile coarse quartz sand (2-mm diameter) moistened with saturated $\mathrm{CaSO}_{4}$ solution. After $2 \mathrm{~d}$ the germinated peanut seedlings were inoculated with Bradyrhizobium strain (Arachis) 3201 (originally isolated from peanut root nodules in calcareous soil) and were planted in the rhizoboxes. Maize seeds were planted $10 \mathrm{~d}$ later than peanut. In the intercropping treatments, peanut seeds were planted in the major compartments, and maize was planted on the PVC separated plate. Therefore, maize roots were divided into two parts, the majority grew in the major compartment and a few grew in the minor compartment. The plants were grown at $26^{\circ} \mathrm{C} / 20^{\circ} \mathrm{C}$ and $14 \mathrm{~h} / 10 \mathrm{~h}$ day / night cycles with a relative humidity of $70-75 \%$. Soil water content was maintained at about $80 \%$ of field capacity $(20 \%)$ by daily supply of water. The daily fluctuation of water content in the soil before and after the daily irrigation was $10-12 \%$ and $13-17 \%$. The soil is a very sandy calcareous soil with good penetrability and poor water retention ability. There were six plants in each rhizobox of monocropping and intercropping system respectively. The ratio of peanut to maize was $1: 1$ in the intercropping treatments.

\section{Plant analysis.}

Plant harvest: After $60 \mathrm{~d}$ growth, the peanut plants were harvested and separated into shoots, roots, and nodules, and maize plants were separated into shoots and roots. Plants were oven dried at $80^{\circ} \mathrm{C}$ for $48 \mathrm{~h}$ and ground. The whole growth period of peanut is about
$150 \mathrm{~d}$, so $60 \mathrm{~d}$ growth would be an early stage of growth i.e. the flowering stage of peanut.

Chlorosis: The chlorophyll SPAD value of the young leaves of peanut in the monocropping and intercropping system was determined by using SPAD-202 chlorophyll apparatus.

Acetylene reduction activity: Roots samples washed with distilled water were placed in $650 \mathrm{~mL}$ mannitol bottles and sealed with a rubber septum. Acetylene (50 $\mathrm{mL}$ ) was injected into the bottles which was then incubated without light at $25^{\circ} \mathrm{C}$ for $1 \mathrm{~h}$. A $0.5 \mathrm{~mL}$ gas sample from each bottle was obtained by microinjector. The release capacity of ethylene was determined by GC-14B Shimadzu gas chromatograph (detector: FID, determined condition: column temperature $80^{\circ} \mathrm{C}$, injector port temperature $100^{\circ} \mathrm{C}$, detector temperature $150^{\circ} \mathrm{C}, \mathrm{N}$ flow $50 \mathrm{~mL} \mathrm{~min}^{-1}$, hydrogen flow $50 \mathrm{~mL} \mathrm{~min}^{-1}$, air flow $500 \mathrm{~mL} \mathrm{~min}^{-1}$ ).

Total $\mathrm{N}$ of plants: Plant shoots and roots of maize and peanut, and nodules of peanut were dried at $80^{\circ} \mathrm{C}$ for $48 \mathrm{~h}$ and ground. The $\mathrm{N}$ content of plant samples was analyzed by Kjeldahl digestion and colorimetric determination of ammonium in the digests by an automated indophenol blue method (Schuman et al. 1973).

Total Fe of plants: Plant shoots, roots, and nodules of peanut were dry ashed at $550^{\circ} \mathrm{C}$ for about $10 \mathrm{~h}$ and the ash dissolved in $1: 30(\mathrm{v} / \mathrm{v}) \mathrm{HNO}_{3}$, the concentration of total $\mathrm{Fe}$ in shoots, roots, and nodules were determined by atomic absorption spectrophotometry.

The concentration of $\mathrm{NO}_{3}^{-}$ion in the soil samples was determined within $24 \mathrm{~h}$ of plant harvest. Soil samples (12 g wet weight) were shaken for $1 \mathrm{~h}$ with $100 \mathrm{~mL}$ $0.01 \mathrm{~mol} \mathrm{~L}^{-1} \mathrm{CaCl}_{2}$. The extract was filtered over a 11 $\mathrm{cm}$ diameter ash-less filter paper. The amounts of $\mathrm{NO}_{3}{ }^{-}$
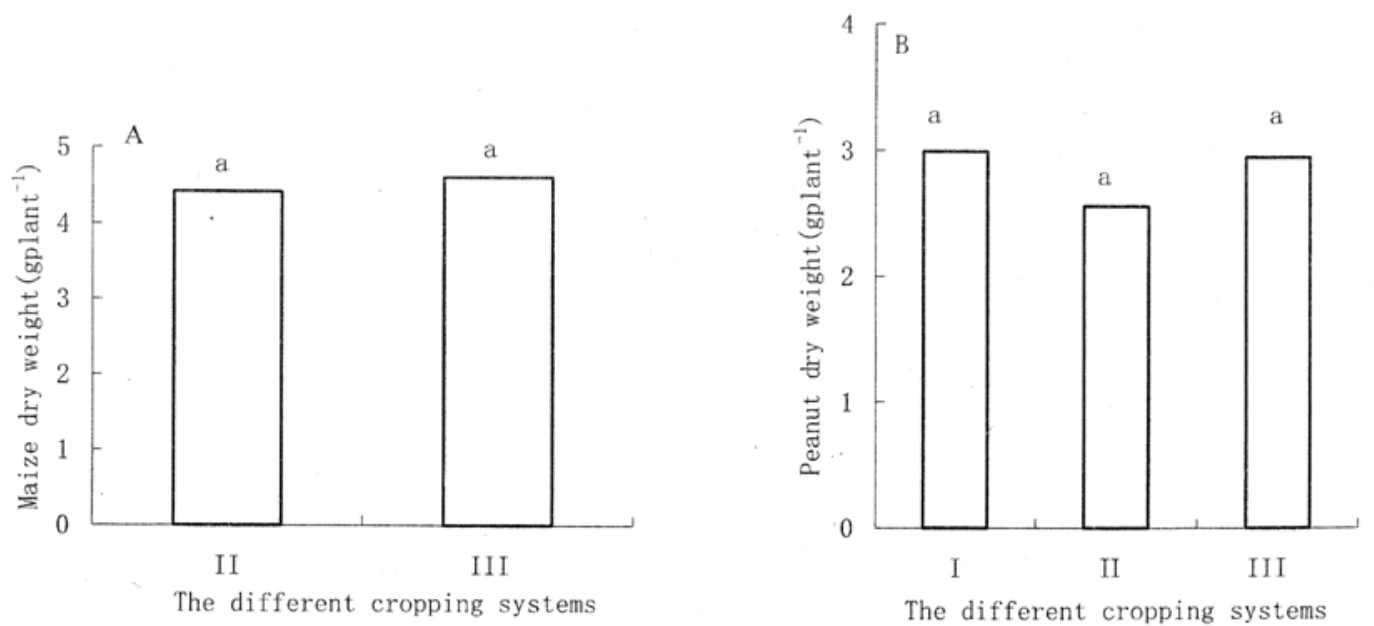

Fig. 2. Peanut and maize dry weight per plant in the different cropping systems. Treatments: I, peanut monocropping; II, maize / peanut intercropping (the major and the minor compartments with low $\mathrm{N} 50 \mathrm{mg} \mathrm{kg}^{-1}$ ); III, maize/ peanut intercropping (the major compartment with low $\mathrm{N} 50 \mathrm{mg} \mathrm{kg}^{-1}$ and the minor compartment with high $\mathrm{N} 200 \mathrm{mg} \mathrm{kg}^{-1}$ ). 
in the extracts were determined colorimetrically using a continuous flow analyzer (TRAACS 2000).

Test of significance. Significant differences in the data between each treatment were estimated by Duncan's multiple-range test.

\section{RESULTS}

\section{Effects of peanut intercropping with maize on the growth of plants dry weight}

The dry weight of peanut and maize was not significantly different in different cropping systems (Fig. 2). That is to say, it was not serious for peanut plants to encounter nutritional stress from $\mathrm{N}$ competition of maize in the intercropping system at the early stages

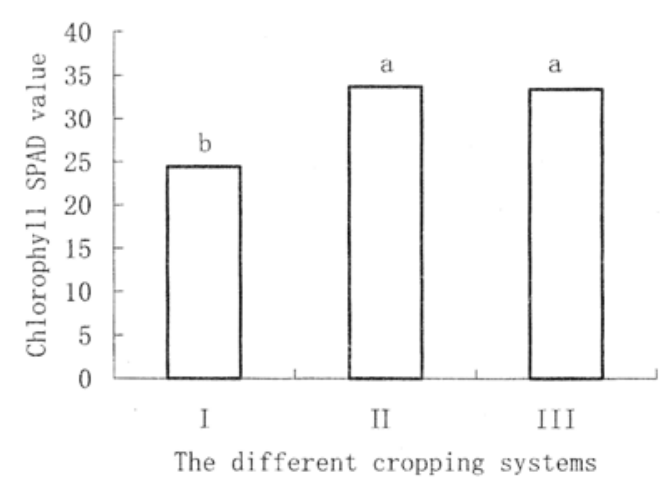

Fig. 3. The chlorophyll content in the young leaves of peanut in the different cropping systems. Treatments: I, peanut monocropping; II, maize/peanut intercropping (the major and the minor compartments with low N $50 \mathrm{mg} \mathrm{kg}^{-1}$ ); III, maize / peanut intercropping (the major compartment with low $\mathrm{N} 50 \mathrm{mg} \mathrm{kg}^{-1}$ and the minor compartment with high $\mathrm{N} 200 \mathrm{mg} \mathrm{kg}^{-1}$ ). of growth.

\section{The effects of peanut intercropping with maize on Fe nutrition of peanut plants}

The chlorophyll readings in the young leaves of peanut in the two treatments of the intercropping system were respectively higher 38 and $36 \%$ than that of peanut in the monocropping system. The chlorophyll content in the young leaves of peanut in the intercropping system (treatment II and III) was obviously enhanced (Fig. 3). Thus, maize in the intercropping systems markedly improved the Fe nutrition and corrected $\mathrm{Fe}$ chlorosis of peanut plants.

Iron uptake in the organs of peanut in the intercropping system (treatment II and III ) was higher than that of the monocropping treatment (Table 1). Compared with the monocropping treatment, Fe uptake increased from intercropping treatment II and III by 22 and $24 \%$ per plant, 30 and $29 \%$ shoots, 38 and $60 \%$ nodules. Iron concentration of shoots of the intercropping treatment II and III were increased 52 and $33 \%$, respectively. Iron uptake in roots was unaffected by treatments. Both $\mathrm{Fe}$ uptake of nodule and Fe concentration of peanut shoot of the intercropping treatment II and III were significantly higher than those of the monocropping treatment (Table 1). Thus, peanut intercropping with maize improved Fe nutrition of peanut plant and especially increased $\mathrm{Fe}$ uptake in nodule and peanut shoot.

\section{The effects of peanut intercropping with maize on $\mathrm{N}$ nutrition of peanut plants}

Nitrogen uptake of peanut in the monocropping system was not higher than that of either intercropping treatments (Table 2). Thus, $\mathrm{N}$ transfer into various organs of peanut was not significantly different in two

Table 1. Fe concentration and uptake in the organs of peanut in different cropping systems.

\begin{tabular}{|c|c|c|c|c|c|c|c|}
\hline \multirow{2}{*}{ Treatments } & \multicolumn{3}{|c|}{ Fe concentration $\left(\mathrm{mg} \mathrm{kg}^{-1}\right)$} & \multicolumn{4}{|c|}{ Fe uptake $\left(\mu \mathrm{g} \mathrm{plant}^{-1}\right)$} \\
\hline & Shoot & Root & Nodule & Shoot & Root & Nodule & Whole plant \\
\hline I & $252.1 \mathrm{~b}$ & $735.7 \mathrm{a}$ & $684.3 \mathrm{a}$ & $685.1 \mathrm{~b}$ & $171.5 \mathrm{a}$ & $13.5 \mathrm{~b}$ & $870.1 \mathrm{~b}$ \\
\hline II & $385.1 \mathrm{a}$ & $595.1 \mathrm{a}$ & $612.2 \mathrm{a}$ & $893.3 \mathrm{a}$ & $150.8 \mathrm{a}$ & $18.5 \mathrm{a}$ & $1,062.6 \mathrm{a}$ \\
\hline III & $335.2 \mathrm{a}$ & $621.3 \mathrm{a}$ & $612.7 \mathrm{a}$ & $882.9 \mathrm{a}$ & $175.4 \mathrm{a}$ & $21.5 \mathrm{a}$ & $1,079.8 \mathrm{a}$ \\
\hline
\end{tabular}

With each treatment, means in the same column and with different letters are significantly different $(p<0.05)$. Mean of four replications. Fe uptake $\left(\mu \mathrm{g} \mathrm{plant}^{-1}\right)=\mathrm{Fe}$ concentration $\left(\mathrm{mg} \mathrm{kg}^{-1}\right) \times$ dry weight $\left(\mathrm{g} \mathrm{plant}^{-1}\right)$.

Table 2. N concentration and uptake in the organs of peanut in different cropping systems.

\begin{tabular}{|c|c|c|c|c|c|}
\hline \multirow{2}{*}{ Treatments } & \multicolumn{2}{|c|}{$\mathrm{N}$ concentration $\left(\mathrm{g} \mathrm{kg}^{-1}\right)$} & \multicolumn{3}{|c|}{$\mathrm{N}$ uptake (mg plant ${ }^{-1}$ ) } \\
\hline & Shoot & Root & Shoot & Root & Whole plant \\
\hline I & $25.9 \mathrm{a}$ & $21.9 \mathrm{a}$ & $70.8 \mathrm{a}$ & $5.6 \mathrm{a}$ & $75.7 \mathrm{a}$ \\
\hline II & $25.6 \mathrm{a}$ & $21.3 \mathrm{a}$ & $59.4 \mathrm{a}$ & $5.5 \mathrm{a}$ & $64.9 \mathrm{a}$ \\
\hline III & $24.9 \mathrm{a}$ & $20.5 \mathrm{a}$ & $65.7 \mathrm{a}$ & $6.3 \mathrm{a}$ & $72.0 \mathrm{a}$ \\
\hline
\end{tabular}

With each treatment, means in the same column and with different letters are significantly different $(p<0.05)$. Mean of four replications. $\mathrm{N}$ uptake $\left(\mathrm{mg}\right.$ plant $\left.{ }^{-1}\right)=\mathrm{N}$ concentration $\left(\mathrm{g} \mathrm{kg}^{-1}\right) \times$ dry weight $\left(\mathrm{g} \mathrm{plant}^{-1}\right)$. 


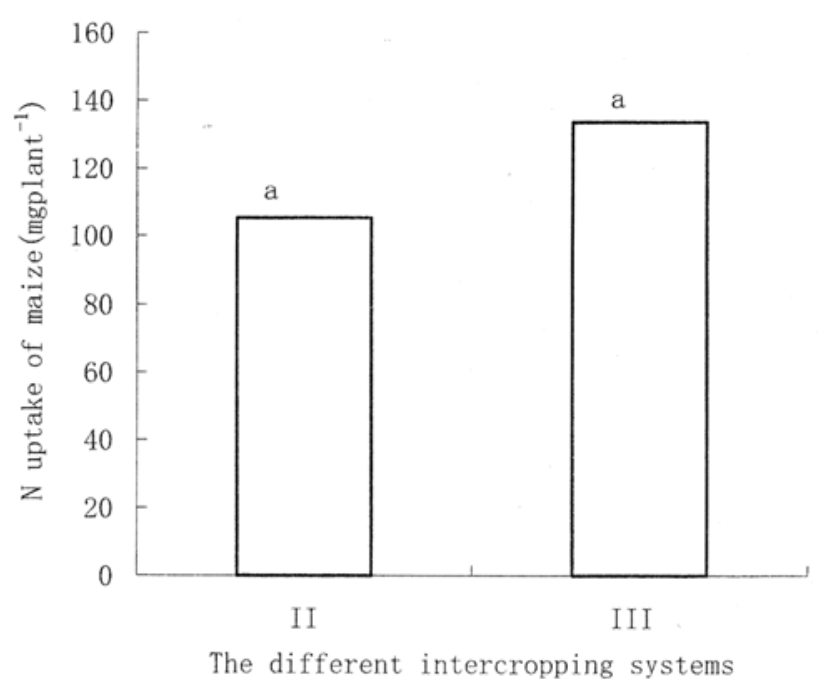

Fig. 4. Maize $\mathrm{N}$ uptake per plant in the different intercropping systems. Treatments: II, maize/peanut intercropping (the major and the minor compartments with low $\mathrm{N} 50 \mathrm{mg} \mathrm{kg}^{-1}$ ); III, maize / peanut intercropping (the major compartment with low $\mathrm{N}$ $50 \mathrm{mg} \mathrm{kg}^{-1}$ and the minor compartment with high $\mathrm{N} 200 \mathrm{mg} \mathrm{kg}^{-1}$ ).

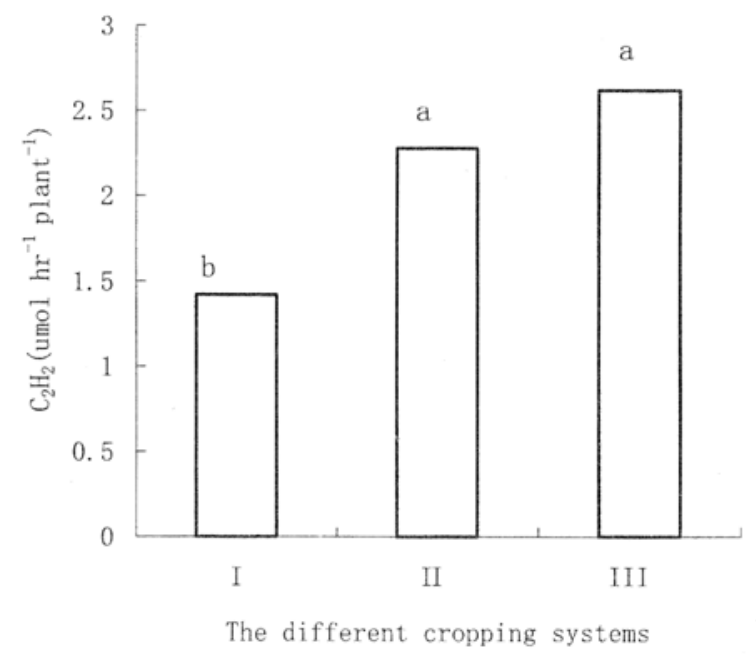

Fig. 5. Effects of intercropping on total acetylene reduction activity of peanut. Treatments: I, peanut monocropping; II, maize / peanut intercropping (the major and the minor compartments with low $\mathrm{N} 50 \mathrm{mg} \mathrm{kg}^{-1}$ ); III, maize / peanut intercropping (the major compartment with low $\mathrm{N} 50 \mathrm{mg} \mathrm{kg}^{-1}$ and the minor compartment with high $\mathrm{N} 200 \mathrm{mg} \mathrm{kg}^{-1}$ ).

cropping systems studied. Ultimately, there was no serious effect of the competition of $\mathrm{N}$ from intercropping maize on $\mathrm{N}$ nutrition of peanut at the early stages of growth. In addition, $\mathrm{N}$ uptake of maize in the intercropping treatment III was not significantly different than that of treatment II (Fig. 4).

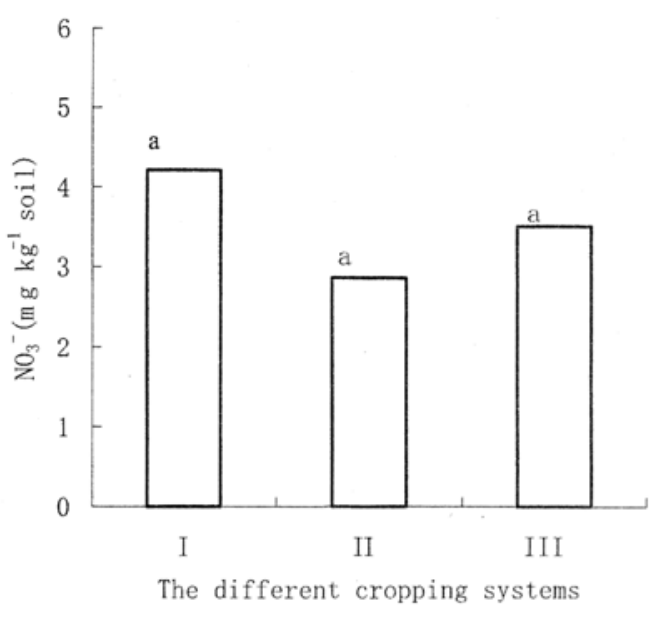

Fig. 6. $\mathrm{NO}_{3}{ }^{-}$concentration in the rhizosphere soil of peanut in the different treatments. Treatments: I, peanut monocropping; II, maize / peanut intercropping (the major and the minor compartments with low $\mathrm{N} 50 \mathrm{mg} \mathrm{kg}^{-1}$ ); III, maize / peanut intercropping (the major compartment with low $\mathrm{N} 50 \mathrm{mg} \mathrm{kg}^{-1}$ and the minor compartment with high $\mathrm{N} 200 \mathrm{mg} \mathrm{kg}^{-1}$ ).

The effects of peanut intercropping with maize on acetylene reduction activity (ARA) of peanut plants

The acetylene reduction activity (ARA) of single peanut plants of both the intercropping treatment II and III were significantly higher than that of the monocropping treatment (Fig. 5), averaging 1.60 and 1.84 times higher than the monocropping treatment respectively. However, the two intercropping treatments were statistically similar.

The effects of peanut intercropping with maize on $\mathrm{NO}_{3}{ }^{-}$concentration of peanut soil rhizophere

Nitrate concentration in the rhizosphere soil of monocropped peanut was not significantly different than that in the intercropping treatments (Fig. 6).

\section{DISCUSSION}

Improvement in peanut $\mathrm{Fe}$ nutrition in intercropping systems. Our results from rhizobox experiment made clear that peanut intercropping with maize could obviously correct $\mathrm{Fe}$ chlorosis of peanut (Fig. 3), increase Fe uptake of peanut, and especially enhance $\mathrm{Fe}$ uptake of nodule (Table 1). Zuo et al. (2000) reported that in the intercropping system, maize not only acquired adequate $\mathrm{Fe}$ to meet its own demand, but also improved the $\mathrm{Fe}$ status of peanut. The results strongly suggest that the improvement of Fe nutritional status of peanut intercropped with maize was mainly attributable to the rhizosphere effect of maize. The rhizosphere effect of maize in intercropping system could keep a 
higher ferric reduction capacity for a longer time period and the relatively fine root morphology of peanut roots which may have assisted in the mobilization of sparingly soluble $\mathrm{Fe}(\mathrm{III})$ compounds from the apoplasmic $\mathrm{Fe}$ pool or the growth medium so that the peanut plants remained green. Another possibility is that maize released phytosiderophores into the rhizosphere of peanut and helped to make more root apoplasmic Fe available to peanut in mixture than in monoculture. Thus, it is possible that peanut plants grown as mixed crops may have higher apoplastic $\mathrm{Fe}$ concentration and be able to make more efficient use of the apoplasmic Fe pool than in monocropping (Bienfait et al. 1985; Zuo et al. 2003). Our results showed that maize/peanut intercropping improved significantly DTPA-Fe concentration of the soil rhizophere of peanut (data not shown). Zuo (1997) also found that DTPA-Fe concentration of rhizophere soil under intercropping was significantly higher than that of monocropped peanut. Roots of peanut and maize shared a common rhizosphere in the intercropping system, so DTPA-Fe concentration of rhizophere soil of the intercropping peanut was increased. This might explain the improvement of peanut Fe nutrition in maize/peanut intercropping system. Some have suggested shading can also have a great effect in improvement of Fe nutrition in plants (Pushnik and Miller 1982; Terry 1983; Bughio et al. 1997), but during our experiment, rhizoboxes were often moved to allow adequate sunlight. Thus, shading from maize was negligible and not a contributing factor.

Effects of the improvement of peanut $\mathrm{Fe}$ nutrition and maize $\mathrm{N}$ competition on $\mathrm{N}_{2}$ fixation of peanut. Iron is an import nutrient in $\mathrm{N}_{2}$-fixing legume root nodules. Iron supplied to the nodule is used by the plant for the synthesis of leghemoglobin, while in the bacteroid fraction it is used as an essential cofactor for the bacterial $\mathrm{N}_{2}$-fixing enzyme, nitrogenase, and $\mathrm{Fe}$-containing proteins of the electron transport chain (Kaiser et al. 2003). Iron appears to be required in greater amounts for nodule formation and function than for host legume growth (Tang et al. 1990). Nodule initiation and development are strongly dependent on $\mathrm{Fe}$ supply, but the stage of nodule initiation or development most sensitive to Fe deficiency appears likely to vary with legume species (Tang et al. 1992; Pike et al. 1997). Iron deficiency resulted in decreased nodule number and nodule mass in chickpea, lentil (Rai et al. 1982, 1984), French bean (Hemantaranjan 1988), and peanut (O'Hara et al.1988a). Iron deficiency generally decreases nodule formation, leghemoglobin production, and nitrogenase activity, leading to low $\mathrm{N}$ concentrations in the shoots in some legumes. More $\mathrm{Fe}$ is required for plants reliant on $\mathrm{N}_{2}$ fixation than for plants supplied with mineral nitrogen (Tang et al. 1992). It has also been shown that $\mathrm{Fe}$ deficiency in peanut induced $\mathrm{N}$ deficiency due to inhibi- tion of the development of nodules (O'Hara et al. 1988b). Our results showed that peanut mixed cropping with maize remarkably improved Fe nutrition of peanut plants, and particularly increased total Fe uptake of peanut root nodule (Table 1). Therefore, the improvement in $\mathrm{Fe}$ nutrition of peanut intercropped with maize improved $\mathrm{N}_{2}$-fixation compared to peanut with Fe deficiency in monocropping system (Fig. 5).

A legume-non-legume intercropping can be defined as any form of cropping in which there is direct competition between two different crop species. In addition, where soil (one being a legume) $\mathrm{N}$ fertility is high, legumes in the field thrive without fixing atmospheric $\mathrm{N}_{2}$, so high levels of soil nitrate can be a potent inhibitor of $\mathrm{N}_{2}$ fixation (Streeter 1988). In intercropping systems, competition for soil mineral $\mathrm{N}$ between legumes and cereals can result in stimulation of biological $\mathrm{N}_{2}$ fixation and increased harvest of total interplanted crops (Rerkasem et al. 1988; Chandel et al. 1989; Peoples et al. 1995; Elabbadi et al. 1996). Both the competition of $\mathrm{N}$ from intercropping maize and the improvement of $\mathrm{Fe}$ nutrition of peanut could promote $\mathrm{N}_{2}$ fixation of peanut in this intercropping system. Our experimental results showed that the improvement of peanut $\mathrm{Fe}$ nutrition in the intercropping system at the early stages of growth (only $60 \mathrm{~d}$ ) was an important factor, which led to enhancement of peanut $\mathrm{N}_{2}$ fixation. There were three reasons to support this idea. First, despite the intercropping system having potential competition for $\mathrm{N}$, there was no significantly difference in $\mathrm{N}$ concentration and uptake of peanut in different treatments at harvest, nor difference in $\mathrm{NO}_{3}{ }^{-}-\mathrm{N}$ concentration of peanut rhizosphere soil in different treatments (Table 2, Fig. 6). On the other hand, maize / peanut intercropping could correct $\mathrm{Fe}$ chlorosis of peanut, increase $\mathrm{Fe}$ transport into the organs of peanut-Fe uptake of nodule and Fe concentration of peanut shoots in different treatments were especially affected (Table 1, Fig. 3). These results indicate that improvement of peanut Fe nutrition was a more important effect on peanut than $\mathrm{N}$ competition from maize in the intercropping system at the early stages of growth. Second, the competition of $\mathrm{N}$ from the intercropping maize hardly affected $\mathrm{N}_{2}$ fixation of peanut when the ratio of maize/peanut was 1:1 in the intercropping treatment. If there had been a difference in acetylene reduction activity between treatment I and II attributed to the competition of $\mathrm{N}$, the nitrogenase activity of peanut should be significantly different between treatment II and treatment III which was eliminated the competition of $\mathrm{N}$ (compared to treatment II), but the fact was not so (Fig. 5). The effects of the competition of $\mathrm{N}$ from the intercropping maize on $\mathrm{N}_{2}$ fixation of peanut under this planting mode at the early stages of growth was not obvious. Third, $\mathrm{NO}_{3}-\mathrm{N}$ markedly affected the 
number of nodule initials of monocropped peanut, while maize / peanut intercropping did not affect it (data not shown).

In conclusion, the results of our experiments strongly support that the improvement in $\mathrm{N}_{2}$ fixation of peanut was mainly attributed to the improvement of Fe nutrition in the intercropping peanut. The competition of $\mathrm{N}$ from intercropping maize had little effect on $\mathrm{N}_{2}$ fixation in peanut in this experiment.

The related mechanisms of improvement of Fe nutrition and competition for $\mathrm{N}$ nutrition on $\mathrm{N}_{2}$ fixation in peanut in this intercropping system are much less understood. Further research is required to elucidate fully the respective contribution of $\mathrm{Fe}$ and $\mathrm{N}$ nutrition of peanut to $\mathrm{N}_{2}$ fixation in intercropping system. Further characterization of effects of the improvement $\mathrm{Fe}$ nutrition of peanut intercropped with maize on nodule formation and development, $\mathrm{N}_{2}$ fixation functions of peanut is currently in progress.

Acknowledgments. We thank the National Natural Science Foundation of China (Grant No. 30170185) and the Major State Basic Research Development Program of the People's Republic of China (Grant No. G1999011707) for financial support.

\section{REFERENCES}

Benson HP, Levier K, and Guerinot ML 2004: A dominant-negative fur mutation in Bradyrhizobium japonicum. J. Bacteriol., 186, 1409-1414

Bienfait HF, van der Briel W, and Mesland-Mul NT 1985: Free space Fe pools in roots: Generation and mobilization. Plant Physiol., 78, 596-600

Bughio N, Takahashi M, Yoshimura E, Nishizawa NK, and Mori S 1997: Light-dependent iron transport into isolated barely chloroplasts. Plant Cell Physiol., 38, 101-105

Chandel AS, Pandey KN, and Saxena SC 1989: Symbiotic nitrogen fixation and nitrogen benefits by nodulated soybean (Glycine max (L.) Merrill) to interplanted crops in northern India. Trop. Agric., 66, 73-77

Dakora DF 1995: A functional relationship between leghemoglobin and nitrogenase based on novel measurements of the proteins in legume root nodules. Ann. Bot., 15, 49-54

Dakora DF 1998: Nodule function in symbiotic bambara groundnut (Vigna subterranea L.) and kersting's bean (Macrotyloma geocarpum L.) is tolerant of nitrate in the root medium. Ann. Bot., 82, 687-690

Elabbadi K, Ismaili M, and Materon LA 1996: Competition between Medicago truncatula and wheat for ${ }^{15} \mathrm{~N}$ labeled soil nitrogen and influence of phosphorus. Soil Biol. Biochem., $\mathbf{2 8}, 83-88$

Hemantaranjan A 1988: Iron fertilization in relation to nodulation and nitrogen fixation in French bean (Phaseolus vulgaris L.). J. Plant Nutr., 11, 829-842

Ito O, Matsunaga S, and Tobita J 1997: Nitrogen fertilizer management in pigeonpea / sorghum intercropping on an Alfisol in the semi-arid tropics. In Plant Nutrition-for Sustainable Food Production and Environment, p. 690-698, Kluwer Academic Publishers, Tokyo, Japan

Jensen ES 1996: Grain yield, symbiotic $\mathrm{N}_{2}$ fixation and interspecific competition for inorganic $\mathrm{N}$ in pea-barley intercrops. Plant Soil, 182, 25-38

Johnston AWB, Yeoman KH, and Wexler M 2001: Metals and the rhizobial-legume symbiosis-uptake, utilization and signaling. Adv. Microb. Physiol., 45, 113-156

Kaiser BN, Moreau S, Castelli J, Thomson R, Lambert A, Bogl S, Puppo A, and Day DA 2003: The soybean NRAMP homologue, GmDMT1, is a symbiotic divalent metal transporter capable of ferrous iron transport. Plant J., 35, 295304

Karpenstein-Machan M and Stuelpnagel R 2000: Biomass yield and nitrogen fixation of legumes monocropped and intercropped with rye and rotation effects on a subsequent maize crop. Plant Soil, 2, 215-232

Levier K 1996: Iron uptake by symbiosynthesis from soybean root nodules. Plant Physiol., 111, 613-618

O'Hara GW, Dilworth MJ, Boonkerd N and Parkplan P 1988a: Iron-deficiency specifically limits nodule development in peanut inoculated with Bradyrhizobium sp. New Phytol., 108, $51-57$

O'Hara GW, Dilworth MJ, Boonkerd N, and Parkplan P 1988b: Response to Bradyrhizobium strains of peanut cultivars grown under iron stress. J. Plant Nutr., 11, 843-852

Peoples MB, Herridge DF, and Ladha JK 1995: Biological nitrogen fixation: An efficient source of nitrogen for sustainable agricultural production? Plant Soil, 174, 3-28

Pike CM, Johnson GV, and Gore JM 1997: The role of iron in nodule initiation and development and nitrogen fixation by soybean. Abstracts of IX International Symposium on Iron Nutrition and Interactions in Plants, p. 29, Hohenheim University, Stuttgart

Pushnik JC and Miller GW 1982: The effects of iron and light treatments on chloroplast composition and ultrastucture in iron deficient barley leaves. J. Plant Nutr., 5, 311-321

Rai R, Prasad V, Choudhury SK, and Sinha NP 1984: Iron nutrition and symbiotic $\mathrm{N}_{2}$ fixation of lentil (Lens culinaris) genotypes in calcareous soil. J. Plant Nutr., 7, 399-405

Rai R, Singh SN, and Prasad V 1982: Effect of press mud amended pyrite on symbiotic $\mathrm{N}_{2}$ fixation, active iron contents of nodules, grain yield and quality of chickpea (Cicer arietinum Linn) genotypes in calcareous soil. J. Plant Nutr., 5, 905-913

Rerkasem B, Rerkasem K, Peoples MB, Herridge DF, and Bergersen FJ 1988: Measurement of $\mathrm{N}_{2}$ fixation in maize ( $\mathrm{Zea}$ mays L.) - ricebean (Vigna umbellata [Thunb.] Ohwi and Ohashi) intercrops. Plant Soil, 108, 125-135

Schuman GE, Stanley MA, and Knudsen D 1973: Automated total nitrogen analysis of soil and plant samples. Soil Sci. Soc. Am. Proc., 37, 480-481

Streeter J 1988: Inhibition of legume nodule formation and $\mathrm{N}_{2}$ fixation by nitrate. CRC Crit. Rev. Plant Sci., 7, 1-23

Tang C, Robson AD, and Dilworth MJ 1990: A split-root experiment shows that iron is required for nodule initiation in Lupinus angustifolius L. New Phytol., 115, 243-250

Tang C, Robson AD, and Dilworth MJ 1992: The role of iron in the (brady) rhizobium legume symbiosis. J. Plant Nutr., 15, 
2235-2252

Terry N 1983: Limiting factors in photosynthesis. IV. Iron stress-mediated changes in light-harvesting and electron transport capacity and its effect on photosynthesis in vivo. Plant Physiol., 71, 855-860

Terry RE, Soerensen KU, Jolley VD, and Brown JC 1991: The role of active Bradyrhizobium japonicum in iron stress response of soybeans. Plant Soil, 130, 225-230

Wexler M, Todd JD, Kolade O, Bellini D, Hemmings AM, Sawers G, and Johnston AWB 2003: Fur is not the global regulator of iron uptake genes in Rhizobium leguminosarum. Microbiology, 149, 1357-1365
Zuo YM 1997: Effects of the intercropping of maize with peanut on iron nutrition of peanut plants in calcareous soil. Ph.D. Dissertation, Department of Plant Nutrition, China Agricultural University, Beijing (in Chinese)

Zuo YM, Li XL, Cao YP, Zhang FS, and Christie P 2003: Iron nutrition of peanut enhanced by mixed cropping with maize: Possible role of root morphology and rhizosphere microflora. J. Plant Nutr., 26, 2093-2110

Zuo YM, Zhang FS, Li XL, and Cao YP 2000: Studies on the improvement in iron nutrition of peanut by intercropping with maize on a calcareous soil. Plant Soil, 220, 13-25 